\title{
טִ
}

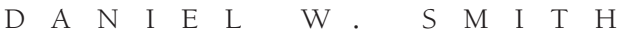 \\ The Inverse Side of the Structure: Žižek on Deleuze on Lacan*}

IN AN INTERVIEW IN 1995, shortly before his death, Gilles Deleuze was asked by French scholar Didier Eribon about his relationship with Jacques Lacan. In response, Deleuze told the following story:

Lacan noticed me when he devoted a session of his seminar to my book on Sacher-Masoch [1967]. ${ }^{1}$ I was told—although I never knew anything more than this - that he had devoted more than an hour to my book. And then he came to a conference at Lyon, where I was then teaching. He gave an absolutely unbelievable lecture.... It was there that he uttered his famous formula, "Psychoanalysis can do everything except make an idiot seem intelligible." After the conference, he came to our place for dinner. And since he went to bed very late, he stayed a long time. I remember: it was after midnight and he absolutely had to have a special whisky. It was truly a nightmare, that night.

My only great encounter with him was after the appearance of AntiOedipus [1972]. . I'm sure he took it badly. He must have held it against us, Félix and me. But finally, a few months later, he summoned methere's no other word for it. He wanted to see me. And so I went. He made me wait in his antechamber. It was filled with people, I didn't know if they were patients, admirers, journalists.... He made me wait a long time-a little too long, all the same-and then he finally received me. He rolled out a list of all his disciples, and said that they were all worthless [nuls] (the only person he said nothing bad about was Jacques-Alain Miller). It made me smile, because I recalled Binswanger telling the story of a similar scene: Freud saying bad things

\footnotetext{
*In this issue's review section, Daniel W. Smith and Eleanor Kaufman review Slavoj Žižek's Organs without Bodies: On Deleuze and Consequences (New York: Routledge, 2004, pp. xii + 217. \$21.95 paper) and Žižek responds. Such review fora, of which this is the first, will be a regular feature of Criticism.
} 
about Jones, Abraham, etc. And Binswanger was shrewd enough to assume that Freud would say the same thing about him when he wasn't there. So Lacan was speaking, and everyone was condemned, except Miller. And then he said to me, "What I need is someone like you" [C'est quelqu'un comme vous qu'il me faut.]. ${ }^{3}$

This is a revealing anecdote, for at least two reasons. First, one might say that the disciple Lacan wound up "getting" was not Gilles Deleuze but Slavoj Žižek (among others), which puts Žižek's encounter with Deleuze in Organs without Bodies (hereafter, $O B$ ) in an interesting retrospective light. Second, and more importantly, Deleuze's personal encounter with Lacan took place after the publication of Anti-Oedipus (hereafter, AO) in 1972. Anti-Oedipus presents, among other things, a famous critique (though not rejection) of psychoanalysis, which Deleuze and Guattari pursued, in part, by means of an engagement with Lacan's work. In this sense one could say that Deleuze was indeed a Lacanian, but in the exact same manner that he was a Spinozist or a Leibnizian: he was neither a slavish follower nor a dogmatic reader of Lacan, but followed the internal trajectory of Lacan's thought to the point where he would push it to its "differential" limit (Deleuze's all-too-well-known image of philosophical "buggery," which makes thinkers produce their own "monstrous" children). Despite Deleuze's initial worries about Lacan's reaction to Anti-Oedipus, Lacan obviously did not dismiss the book. On the contrary, not only was his reading of the book the apparent basis of his "summons" to Deleuze, but he even seems to have been influenced by AntiOedipus in his own thinking. Žižek himself suggests that Lacan's later work (after Seminar XI in 1964) is marked by an increased interest in the theory of the drives and anti-Oedipal themes $(O B$ 102, 176). Given the complex status of the drives that one finds elaborated in Anti-Oedipus (for instance, the thesis that the "drives are part of the infrastructure itself," AO 63), one can assume that Lacan saw Deleuze neither as an antagonistic critic, nor even a potential bearer of orthodoxy (à la Miller), but rather a highly original fellow traveler.

This is what makes Organs without Bodies a bit of a disappointment, as well as a sharp departure from Lacan's own relationship to Deleuze. It is not so much that only about a quarter of Žižek's book (if that) is actually devoted to Deleuze, and the rest is Žižek doing his own thing. It is not even so much that Žižek misreads Deleuze on this or that point: Deleuze himself wrote that "encounters between independent thinkers always occur in a blind zone," and this is certainly true of the encounter between Žižek and Deleuze. ${ }^{4}$ The disappointment is that even though Žižek describes Organs without Bodies as "a Lacanian book on Deleuze" (OB xi), he winds up saying nothing whatsoever about Deleuze's own work on Lacan. This, perhaps, is just a thwarted expectation: I had hoped to find in Žižek's book a kind of guide through the complexities of the Deleuze-Lacan encounter, yet nothing of the sort appears in the book. Instead, early on, Žižek 
quickly and curtly dismisses Anti-Oedipus as "arguably Deleuze's worst book" (21) and immediately turns his attention elsewhere.

In this, Organs without Bodies bears a strange resemblance to Alain Badiou's 1997 book, Deleuze: The Clamor of Being. Badiou had seen Deleuze as his primary rival in developing an "ontology of the multiple," and he opens his book by expressly declaring that the source of his controversy with Deleuze was their differing philosophical conceptions of "multiplicities." Yet as one reads on, one quickly discovers that the book does not contain a single discussion of Deleuze's theory of multiplicities; it ignores the topic entirely. Instead, Badiou is content simply to reiterate, ad nauseum, the dubious claim that Deleuze is really just a thinker of "the One"-almost like a politician avoiding reporters' questions by doggedly sticking to his talking points. Žižek admits that he relied "extensively" on Badiou's reading of Deleuze (OB 20n), and he rather slavishly adopts its theses and winds up reproducing a number of its errors regarding "univocity" and "vitalism" (Deleuze, Žižek dutifully repeats, is "the last great philosopher of the One" [121; cf. 28]). But the resemblance to Badiou is stylistic as well as substantive, since one finds a similar strategy of avoidance and displacement in Žižek's book—a "Lacanian" book on Deleuze that does not contain a single discussion of Deleuze's reading of Lacan. Taking up Deleuze's own image, Žižek claims that he is engaging in a kind of "Hegelian [and, one might add, Lacanian] buggery of Deleuze" (48, italics in original). The ultimate aim of his book is to show us that Deleuze is "much closer to psychoanalysis and Hegel" (xi) than we might have expected-in other words, that Deleuze is really a kind of Žižekian avant la lettre (69). As a result, Žižek's reading of Deleuze, at its most positive, is often little more than a transcription of Deleuze's concepts into Žižek's own Lacanian (and Hegelian) terminology. One does not begrudge Žižek his project-he is certainly one of the most engaging and prolific thinkers alive today-but then one wonders why the detour through Deleuze was necessary at all, except as a kind of exercise in pop-Hegelian sublation.

Nonetheless, there is a serious "reading" of Deleuze taking place in the midst of all the buggery. Žižek issues his perfunctory dismissal of Anti-Oedipus (1972) in order to elevate Logic of Sense (1969) to the status of Deleuze's pivotal work (no doubt, once again, in deference to the master, since Lacan also discussed Logic of Sense in a session of his seminar). Deleuze himself summarized the fundamental question he was attempting to address in the Logic of Sense in the following manner: "How can we maintain both that sense produces even the states of affairs in which it is embodied [sense as a principle of the production of beings], and that it is itself produced by these states of affairs or the actions and passions of bodies [sense as an impassive effect of material causes]?" 6 Zižek feigns a certain surprise that no one (before him) had perceived this tension (production versus effect) that lies at the heart of Logic of Sense, and he claims that it in fact holds the key to Deleuze's entire work (OB 21). The "conceptual edifice" of Deleuze's philosophy, 
Žižek argues, oscillates between these two "logics" of sense (or of the event), which are "fundamentally incompatible" (20). "Is this opposition not that of materialism versus idealism? In Deleuze this means: The Logic of Sense versus Anti-Oedipus" (21). Put summarily, one finds two competing ontologies in Deleuze-one good, the other bad and naive: "sense as effect" is the good ontology, "sense as production" is the bad ontology. Sense as "effect" is good because it is Lacanian: the event is the irruption of the Real within the domain of causality (produced by a "quasi-cause," which Žižek revealingly identifies as both "the exact equivalent of Lacan's objet petit a" [27] as well as Deleuze's "name for the Lacanian "phallic signifier" [93]-thereby conflating the two poles of Lacan's theory of desire that Deleuze kept separate). "The basic premise of Deleuze ontology [in Logic of Sense] is precisely that corporeal causality is not complete. In the emergence of the New, something occurs that cannot be described at the level of corporeal causes and effect" (27). This something is the event, that is, "the point of non-sense sustaining the flow of sense ... [which] fills in the gap of corporeal causality" $(28,27)$. This gap entails a "positive notion of lack, a 'generative' absence" (35), "an irreducible crack in the edifice of Being" (41). This gap is the true domain of politics, since it marks the difference between "the explosion of revolutionary Events" and the "objective' material/socioeconomic processes taking place in reality" (32). Hence the dualism that Badiou establishes between "being" and "event."

For this reason, the sole interpretive question that arises for Žižek is this: how and why did Deleuze move from the beautifully Lacanian Logic of Sense to the misguided and non-Lacanian Anti-Oedipus? The response to this question initially seems ad hominem: the culprit is the Félix Guattari virus that infected Deleuze's thought. Like many others (Derrida, Badiou), Žižek makes a rather easy distinction between the "good" Deleuze (the solo Deleuze) and the "bad" Deleuze (Deleuze with Guattari). Guattari's influence was partly political; the solo Deleuze, Žižek notes, was "a highly elitest author, indifferent to politics" (OB 20). Deleuze himself admitted that Anti-Oedipus had indeed marked a profound transformation in his work: "For my part, I made a sort of move into politics around May 68, as I came into contact with specific problems, through Guattari, through Foucault, through Elie Sambar. Anti-Oedipus was from beginning to end a book of political philosophy." ${ }^{\prime 7}$ But behind the ad hominem musings there lies a more substantive claim: "The only serious philosophical question is what inherent impasse caused Deleuze to turn toward Guattari?” (20). According to Žižek, the impasse was precisely the tension between the good ontology and the bad ontology: "Was Deleuze not pushed toward Guattari because Guattari represented an alibi, an easy escape from the deadlock of his previous position" (21). The easy escape was the abandoning of a good Lacanian ontology (event as effect) for a bad Guattarian ontology (event as production and becoming): "Deleuze deploys the One-Substance as the indifferent medium of multitude" (33). Such, in short, is the upshot of the story that one finds in Žižek's brief engagement with 
Deleuze: a good Lacanian moment in Logic of Sense is immediately betrayed by Anti-Oedipus and the evil Félix Guattari. If Deleuze had stuck with the insights of Logic of Sense, he would have been able to enter into a becoming-Žižek, and not wandered off into the desert of Guattari.

But would it be possible to follow Lacan himself and read Anti-Oedipus as something other than Deleuze's worst book? How can we understand Lacan's own positive reaction to Anti-Oedipus? Is there perhaps a fidelity to Lacan's thought in Anti-Oedipus that is more profound than the rather easy appropriation found in Logic of Sense? Žižek is certainly correct to sense a shift in Deleuze's thought between Logic of Sense and Anti-Oedipus. "The surface-depth problem [of Logic of Sense] no longer concerns me," Deleuze remarked in a 1973 interview. "What interests me now are the relations between a full body, a body without organs, and flows that migrate." ${ }^{8}$ And Žižek is also correct to sense that this shift had something to do with Deleuze's association with Guattari. Deleuze later explained: "Oddly enough, it wasn't me who rescued Félix from psychoanalysis; he rescued me. In my study on Masoch, and then in Logic of Sense, I thought I'd discovered things about the specious unity of sadism and masochism, or about events, that contradicted psychoanalysis but could be reconciled with it. Félix, on the other hand, had been and was still a psychoanalyst, a student of Lacan's, but like a 'son' who already knew that reconciliation was impossible. Anti-Oedipus marks a break."9 But what Žižek does not seem to realize (as Lacan obviously did) is that Deleuze's break with psychoanalysis was brought about by none other than Lacan himself. Anti-Oedipus is, from start to finish, a reading of Lacan, and no doubt it would have had Lacan's name in the title had not so much else been going on in the book. Lacan is often presented as having effected a linguistic and structural reinterpretation of Freud. For Deleuze, however, this is not where Lacan's significance lies. "It's all very well to say to us: you understand nothing, Oedipus, it's not daddy-mummy, it's the symbolic, the law, the arrival of culture, it's the effect of the signifier, it's the finitude of the subject, it's the 'lack-of-being' [manqué-à-être] which is life." ${ }^{10}$ Lacan's significance, rather, lies in the way in which he was able to push psychoanalysis to the point of its auto-critique, and it is precisely this Lacanian critique of psychoanalysis that Deleuze and Guattari take up and pursue in Anti-Oedipus. "There are problems that troubled Freud toward the end of his life: something is not right with psychoanalysis, something is stuck. Freud thought that it was becoming endless, the cure looked interminable, it was going nowhere. And Lacan was the first to indicate how far things had to be revamped." "Despite its reputation, Anti-Oedipus does not contain a single negative comment about Lacan, although it is occasionally critical of the direction his thought was taken by certain of his disciples, and of the orthodoxy that grew up around him.

This is all the more reason to regret the fact that Žižek, as a Lacanian, chose to overlook the Deleuze-Lacan encounter and to dismiss Anti-Oedipus in a way that Lacan himself did not. Perhaps someday a reader with the competence to do so will analyze the outlines and the consequences of this encounter. ${ }^{12}$ Lacking that 
competence, I can at least list a number of points that might be relevant to such an analysis, some of which Žižek has touched on, at least in passing, in his book.

\section{Immanence and Transcendence}

Deleuze has presented himself, famously, as a philosopher of immanence, and his critique of psychoanalysis is undertaken from the perspective of immanence. What Is Philosophy? identifies three types of transcendence that have been constant temptations away from immanence: (1) contemplation, or the transcendence of the Idea (Plato); (2) reflection, or the transcendence of the Subject (Kant); and then (3) a third type, which we might call the transcendence of the Breach or Rupture. "In this modern moment," Deleuze writes, "we are no longer satisfied with thinking immanence as immanent to a transcendent; we want to think transcendence within the immanent, and it is from immanence that a breach is expected." 13 In other words, to cite some well-known examples, it is from within immanence itself that one now seeks to locate "inconsistency" or the "void" (Badiou), or from which one seeks to find a "gap" or "rupture" within immanence, the "irruption" of the Real. Whatever the terminology, Deleuze suggests, it is always the same model_-"making us think that immanence is a prison from which the Transcendent will save us." 14 Žižek candidly admits that this modern model of transcendence is his own model: "Transcendence' is the illusory reflection of the fact that the immanence of phenomena is ruptured, broken, inconsistent" (OB 61). This new conception of transcendence, he notes, no longer refers either to a Beyond (God) or a Subject, but rather to "the gap within immanence" (62). Immanence is what is given, what is actual; we therefore need to discover the breach, the rupture, the gap, the torsion or twist, that will save us from the actuality of the immanent (Being as multiple) through an irruption of the new (the Event, the transcendence within immanence). Žižek then asks the necessary question: "What if this gap in immanence is what Deleuze cannot accept?" (61). And Žižek is indeed correct: Deleuze does not accept this modern appeal to transcendence in psychoanalytic thought. "How many interpretations of Lacanianism," Deleuze asks, "overtly or secretly pious, have in this manner invoked ... a gap in the Symbolic? . . . Despite some fine books by certain disciples of Lacan, we wonder if Lacan's thought really goes in this direction" (AO $83,53)$. In other words, it is out of fidelity to Lacan's thought that Deleuze rejects the appeal to a gap in immanence.

\section{The Status of the Real}

How then does Deleuze break with this model? In certain respects, what is at stake in this question is the status of the Real, in the Lacanian sense, and Žižek recognizes this. "What matters to Deleuze is not virtual reality but the reality of the virtual (which, in Lacanian terms, is the Real)" (OB 3). In fact, Deleuze and Guattari explicitly characterize Anti-Oedipus as being, from start to finish, a theory of 
the Real. "We were unable to posit any difference in nature, any border line, any limit at all between the Imaginary and the Symbolic. . . . The true difference in nature is not between the Symbolic and the Imaginary, but between the Real machinic element, which constitutes desiring-production, and the structural whole of the Imaginary and the Symbolic, which merely forms a myth and its variants" (AO 83). The aim of the book, they tell us, is "to renew, at the level of the Real, the tie between the analytic machine, desire, and production" (53). In their language, the Real = desiring - production. The unconscious "is neither Imaginary nor Symbolic, it is the Real in itself, the 'impossible real' and its production. ... The machines of desire . . constitute the Real in itself, beyond or beneath the Symbolic as well as the Imaginary" (53). (Deleuze and Guattari will nonetheless insist that "the real is not impossible; on the contrary, within the Real everything is possible, everything becomes possible. . . It is only in the structure [the symbolic] that the fusion of desire with the impossible is performed, with lack defined as castration" $[27,306])$. What is it that allows Deleuze to link the Real with the theory of desire in this manner (desire = production)?

\section{The Kantian Theory of Desire}

Anti-Oedipus can be said to find its primary model in the Critique of Practical Reason, since it was Kant who first defined the faculty of desire as a productive faculty ("a faculty which, by means of its representations, is the cause of the actuality of the objects of those representations"). ${ }^{15}$ We know why Kant defined desire in terms of production: the problem of freedom concerns the operation by which a free being can be the cause of something that is not reducible to the causal determinism of mechanism. Of course, Kant was aware that real objects could be produced only by an external causality and external mechanisms; in what he called "pathological" productions of desire, what is produced is merely a psychic reality (having a fantastic, hallucinatory, or delirious object) (AO 25). Nonetheless, this was Kant's Copernican Revolution in practical philosophy: desire is no longer defined in terms of lack (I desire something because I don't have it), but rather in terms of production (I produce the object because I desire it). The fundamental thesis of Anti-Oedipus is a stronger variant of Kant's claim; Kant pushed to his necessary conclusion: "If desire produces, its product is real," and not merely a fantasy (26). "There is no particular form of existence that can be labeled "psychic reality" (27). Indeed, Deleuze states this conclusion in explicitly Lacanian terms: "The objective being of desire is the Real in and of itself" (the subject itself is a product of desire) (27).

\section{Desire and Immanence}

But Deleuze is clearly not a Kantian in any straightforward sense. For Kant, the fundamental question concerns the higher form (nonpathological) of the faculty of desire: a faculty has a higher form when it finds within itself the law of its 
own exercise, and thus functions autonomously. The higher form of desire is what Kant calls the "will": desire becomes will when it is determined by the representation of a pure form (the moral law), which is the pure form of a universal legislation (the categorical imperative). In Kant, however, freedom, as the "fact" of morality, requires as it postulates the three great transcendent Ideas of the Soul, the World, and God. It is precisely the transcendence of the Moral Law that renders its object unknowable and elusive. Was this not what Lacan himself showed in his famous essay "Kant avec Sade," to which Deleuze admits his indebtedness? ${ }^{16}$ Anti-Oedipus can thus be said to have effected an immanent inversion of Kant (though it is no longer concerned with the synthesis of consciousness, but with the syntheses of the unconscious). In the first two chapters of Anti-Oedipus, Deleuze provides a purely immanent characterization of the three syntheses of the unconscious - connection (which forms a counter-Self, and no longer a Soul), conjunction (which forms a "chaosmos" and no longer a World), and disjunction (which exchanges its theological principle for a diabolical one)_and shows how desire (as the principle of production) constitutes the Real by tracing series and trajectories following these syntheses within a given social assemblage. "The Real is the end product, the result of the passive syntheses that engineer partial syntheses of desire as auto-production of the unconscious."17

\section{Lacan's Oscillation}

But, Deleuze asks, was not Lacan's own thought already moving in this immanent direction in 1972? In Anti-Oedipus, Deleuze and Guattari identified two poles in Lacan's theory of desire (which Žižek seems to conflate): "Lacan's admirable theory of desire appears to us to have two poles: one related to 'the object small $a$ ' as a desiring-machine, which defines desire in terms of a real production, thus going beyond any idea of need and any idea of fantasy; and the other related to the 'great Other' as a signifier, which reintroduces a certain notion of lack" (AO 27n). The innovation of Anti-Oedipus was that it attempted to follow the first path laid out by Lacan (an immanent concept of desire related to the objet petit a), despite the efforts of Lacan's "first disciples" (83) to push his thought in the second "Oedipal" direction (desire related to the transcendence of the phallic signifier). Deleuze and Guattari admit that the oscillation between these two poles of desire was present within Lacan's own thought:

We owe to Jacques Lacan the discovery of this fertile domain of a code of the unconscious, incorporating the entire chain-or several chains_-of sense: a discovery thus totally transforming analysis ... The chains are called "signifying chains" because they are made up of signs, but these signs are not themselves signifying. . . If the first disciples were tempted to re-close the Oedipal [Symbolic] yoke, didn't they do so to 
the extent that Lacan seemed to maintain a kind of projection of the signifying chains onto a despotic signifier? . . . The signs of desire, being non-signifying, become signifying in representation only in terms of a signifier of absence or lack." (38, 83, italics added)

Following Lacan, Anti-Oedipus thus attempts to analyze the means by which the legitimate and immanent syntheses of desire (partial connections, inclusive disjunctions, polyvocal conjunctions-the Real production of desire, the objet petit a) are inverted and converted into illegitimate and transcendent syntheses (global connections, exclusive disjunctions, biunivocal conjunctions-the Oedipal or Symbolic representation of desire via the "phallic signifier").

\section{Lacan's Anti-Oedipal Trajectory}

But once again, despite this oscillation, was it not Lacan himself who was pushing psychoanalysis away from Oedipus and the Symbolic? Žižek complains that "what Deleuze presents as 'Oedipus' is a rather ridiculous simplification, if not an outright falsification, of Lacan's position" (OB 80), pointing to the constant references to "au-delà de l'Oedipe" in the last decades of Lacan's teaching. But Deleuze and Guattari would agree with this latter characterization-in their eyes, Lacan is himself the great anti-Oedipal thinker (they approvingly cite Lacan's 1970 claim that "I have never spoken of an Oedipus complex" [AO 53n]). Lacan, they write, "was not content to turn, like the analytic squirrel, inside the wheel of the Imaginary and the Symbolic" (308). The Real is the internal limit to any process of symbolization, but it was not enough for Lacan to describe the Real, negatively, as a resistant kernel within the symbolic process upon whose internalized exclusion the symbolic is constituted (negation or exclusion as constitutive). Rather, Lacan was pushing psychoanalysis to "the point of its self critique" (310), where the Real would be able to appear in all its positivity: "the point where the structure, beyond the images that fill it [fantasies] and the Symbolic that conditions it within representation, reveals its reverse side as a positive principle of nonconsistency that dissolves it" (311, italics added). Deleuze and Guattari thus present Anti-Oedipus as continuing a trajectory that was initiated by Lacan himself. "It was inopportune to tighten the nuts and bolts where Lacan had just loosened them ... The object (small o) erupts at the heart of the structural equilibrium in the manner of an infernal machine, the desiring-machine" (83).

\section{The Real and Schizophrenia}

Deleuze's term for the Real is "schizophrenia as a pure process" (which must be distinguished from the schizophrenic as a clinical entity), and it is with this concept that Deleuze takes Lacan's thought to its limit and conclusion. "It is this entire 
reverse side of the [symbolic] structure that Lacan discovers ... schizophrenizing the analytic field, instead of oedipalizing the psychotic field" (AO 309). Following directions indicated by Lacan himself, Anti-Oedipus attempts to describe the Real in all its positivity: differential partial objects or intensities that enter into indirect syntheses; pure positive multiplicities where everything is possible (transverse connections, polyvocal conjunctions, included disjunctions); signs of desire that compose a signifying chain, but which are themselves non-signifying, and so on (309). The domain of the Real is a "sub-representative field" (300), but Deleuze does not hesitate to claim that "we have the means to penetrate the subrepresentational" (italics added). ${ }^{18}$ Conversely, if the Real is the sub-representative, then "illusion" (if one wants to retain this word) only appears afterward, in the actual: it is only within the symbolic (representation) that desire appears negatively as lack, as castration. It is for this reason that Deleuze suggests that schizophrenia provides a better clue to the nature of the unconscious and the Real than neurosis: psychotics resist therapeutization because they have a libido that is too liquid or viscous, they resist entry into the symbolic (foreclosure), mistaking words for things. But "rather than being a resistance of the ego, this is the intense outcry of all of desiring-production" (67). Some of Deleuze's most profound texts (such as "Louis Wolfson; or, The Procedure") are those that analyze the specifically schizophrenic uses of language, which push language to its limit and lay waste its significations, designations, and translations. ${ }^{19}$ Deleuze suggests that the usual negative diagnostic criteria that have been proposed for schizophrenia-dissociation, detachment from reality, autism - are, above all, useful terms for not listening to schizophrenics. But in the end, this problem is not specific to schizophrenics: "we are all libidos that are too viscous and too fluid . . . [which] bears witness to the non-oedipal quality of the flows of desire" (67; cf. 312).

\section{The Body without Organs}

Hence, whereas Logic of Sense was content to remain at the surface of sense (like Lewis Carroll), Anti-Oedipus can be said to have plunged into the depth of bodies (Artaud): the logic of the passive syntheses (the Real) ultimately finds its model in the body-or more precisely, the "body without organs." 20 This wellknown but complex Deleuzian notion has three fundamental components. Schizophrenics experience their organs in a nonorganic manner, that is, as elements or singularities that are connected to other elements in the complex functioning of a "machinic assemblage" (connective synthesis). But the breakdown of these organ-machines reveals a second theme-that of the body without organs, a nonproductive surface upon which the anorganic functioning of the organs is stopped dead in a kind of catatonic stupor (disjunctive synthesis). These two poles - the vital anorganic functioning of the organs and their frozen catatonic stasis, with all the variations of attraction and repulsion that exist between 
them-can be said to translate the entire anguish of the schizophrenic, which in turn points to a third theme, that of intensive variations (conjunctive synthesis). These poles are never separate from each other, but generate between them various forms in which sometimes repulsion dominates, and sometimes attraction: the paranoid form of schizophrenia (repulsion), and its miraculating or fantastic form (attraction). Schizophrenics tend to experience these oscillating intensities (manic rises in intensity, depressive falls in intensity . . . ) in an almost pure state. Beneath the hallucinations of the senses ("I see," "I hear") and the deliriums of thought ("I think"), there is something more profound, a feeling of intensity-that is, a becoming or a transition ("I feel"). A gradient is crossed, a threshold is surpassed or retreated from, a migration is brought about: "I feel that I am becoming woman," "I feel that I am becoming god," "I feel that I am becoming pure matter. ..." The innovation of Anti-Oedipus is to have penetrated into this sub-representative, schizophrenic domain of the body without organs and made use of it as the model for the unconscious itself. The analysis of this unconscious entails a corresponding practice that Deleuze and Guattari will term "schizoanalysis."

\section{Psychoanalysis and Schizoanalysis}

What then is the difference between psychoanalysis and schizoanalysis? "Psychoanalysis settles on the imaginary [fantasy] and structural [symbolic] representatives of reterritorialization, while schizoanalysis follows the machinic indices of deterritorialization" (AO 316). One can only admire the enthusiasm with which Žižek analyzes the first movement, particularly in his section the "phallus" (the "organ without a body" of the title) (see OB 87-95). The phallus, as the signifier of castration, is what effects a desexualization of the libido, and makes possible the "impossible" passage of the body (the drives) into symbolic thought, the passage from bodily depth to surface event (symbolic castration). Deleuze and Guattari could no doubt even agree with Žižek's claim that Oedipus is an "operator of deterritorialization" (83), insofar as every movement of deterritorialization (of the drives) is accompanied by a reterritorialization (onto the symbolic). "Schizophrenia as a process, deterritorialization as a process," they write, "is inseparable from the stases that interrupt it, aggravate it, or make it turn in circles, and reterritorialize it into neurosis, perversion, and psychosis" (the latter being the three main categories in Lacan's diagnostic schema) (AO 318). Oedipus and castration are indeed realities that psychoanalysis did not invent. But schizoanalysis, by contrast, moves in the exact opposite direction and seeks to locate the indices of deterritorialization, within these reterritorializations, in a completely different manner than psychoanalysis: "not the gaping wound represented in castration [the gap in immanence], but the myriad little connections, disjunctions, and conjunctions" that constitute the real movement of the immanent process of desire (314). Put crudely, psychoanalysis begins with the symbolic and seeks out the "gaps" that 
mark the irruption of an "impossible" Real; whereas schizoanalysis starts with the Real as the immanent process of desire and seeks to mark both the interruptions of this process (reterritorializations) and its continuations and transformations (becomings, intensities... ).

\section{The Assembling of Desire}

The fundamental concept in Deleuze's theory of desire is thus the concept of the assemblage [agencement]. There exists a common but misguided critique of Deleuze and Guattari that claims that in subtracting desire from lack, the law, and castration, they wind up invoking a state of nature, a desire that would be a natural and spontaneous reality that winds up being repressed by society. ${ }^{21}$ But Deleuze and Guattari's argument is precisely the opposite: there is no desire other than assembled [agencé] desire. "Desire is never either a 'natural' or a 'spontaneous' determination . . . never a "natural reality," writes Deleuze, but always results from "a highly developed, engineered setup [montage] rich in interactions," and it can neither be grasped nor conceived apart from a determined social assemblage or apparatus. ${ }^{22}$ Desire, as "desiring-production," is both productive and produced. Within any given assemblage of desire, there are, on the one hand, rigid lines of sedimentation and reterritorialization that tend to "normalize" desire, to "represent" or "symbolize" it; and then, on the other hand, there are supple lines of creativity and deterritorialization (lines of flight or escape) that allow the assemblage to transform itself, or even to break down in favor of a future assemblage. These two types of vectors are immanent to any process of desire, to every "desiring-machine." What mechanisms of repression crush is not desire as a natural given, but precisely these cutting edges of assemblages of desire (the production of the new). ${ }^{23}$ The question at every moment concerns the vector that desire is in the process of constructing or assembling (deterritorialization and reterritorialization). But yet again, one must stress that it was Lacan himself who posed the question of desire in terms of these two poles or vectors: "In Lacan, the symbolic organization of the structure, with its exclusions that come from the function of the signifier, has as its reverse side the real inorganization of desire" (AO 328, italics added; cf. 39).

\section{Desexualization and Political Philosophy}

Finally, a brief comment about the relationship between Deleuze's political philosophy and his theory of desire. Freud held strongly to the hypothesis that the libido does not invest the sociopolitical field except on the condition that it be "desexualized" or "sublimated"-a hypothesis that Žižek takes up and defends ("Sexuality can universalize itself only by way of desexualization" [OB 91]). Deleuze and Guattari explicitly reject this Freudian principle. "Our entire 
hypothesis is, on the contrary, that the social field is invested by a sexual libido as such, and that this is in fact the fundamental activity of the libido." ${ }^{24}$ The concepts of sublimation and desexualization are linked to the implicit familialism of psychoanalysis. "At least in the beginning," the argument goes, the unconscious is expressed in familial relations, and social relations only arise afterward. "Symbolic castration' is a way for the subject to be thrown out of the family network, propelled into a wider social network" (83). Against this familiar Freudian notion, Deleuze and Guattari not only argue that the libido directly invests social relations without any mediation (such as introjection/projection, desexualization/ sublimation, or symbolization), but that this investment is there from the start, at the level of the drives. One of the most profound and far-reaching theses of Anti-Oedipus is that the libidinal economy of Freud and the political economy of Marx are one and the same economy ("affects or drives form part of the infrastructure itself" [AO 53]), even if they have different regimes. The concept of the assemblage is itself derived from this insight. It is not through a desexualizing extension that the libido invests sociopolitical relation; "on the contrary, it is through a restriction, a blockage, and a reduction that the libido is made to repress its flows in order to contain them in the narrow cells of the type 'couple,' 'family,' 'person,' 'objects'" (293). In effect, this thesis is the basis of the political philosophy Deleuze begins to develop in Anti-Oedipus and continues in A Thousand Plateaus, although Žižek seems largely oblivious to it. Hence, it is difficult to know what Žižek means when he characterizes Deleuze as "the ideologist of late capitalism" (184), since he says nothing of either Deleuze's analysis of capitalism or his critique of the concept of ideology.

These points, to be sure, hardly constitute a reading of Anti-Oedipus, one of Deleuze's most difficult and ambitious texts, and can do little more than point toward the direction of future work. But what is striking about Anti-Oedipus is the degree to which Deleuze and Guattari fully admit their indebtedness to Lacan and describe their project as an attempt to take Lacan's profound thought to its differential and immanent conclusion. As Deleuze explained:

Félix had talked to me about what he was already calling "desiringmachines": he had a whole theoretical and practical conception of the unconscious as a machine, of the schizophrenic unconscious. So I myself thought he had gone further than I had. But for all his unconscious machinery, he was still talking in terms of structures, signifiers, the phallus, and so on. That was hardly surprising, since he owed so much to Lacan (just as I did). But I felt it would all work even better if one found the right concepts, instead of using notions that didn't even come from Lacan's creative side, but from an orthodoxy built up around him. Lacan himself says, "I'm not getting much help." We thought we'd give him some schizophrenic help. And there's no question that we're 
all the more indebted to Lacan, once we've dropped notions like structure, the symbolic, or the signifier, which are thoroughly misguided [mauvaises], and which Lacan himself has always managed to turn on their head in order to show their inverse side. ${ }^{25}$

In this sense, Deleuze can be seen as one of Lacan's most profound, but also most independent, disciples, inventing a whole new set of concepts to describe the inverse side of the symbolic structure. He followed a completely different path than the other disciples, such as Jacques-Alain Miller, the keeper of orthodoxy; Alain Badiou, who gives an axiomatic treatment of the symbolic; or Žižek himself, the Lacanian reader of contemporary culture. The admiration Lacan and Deleuze had for each other's work was obviously deep and full of respect. Deleuze once wrote: "My ideal, when I write about an author, would be to write nothing that could cause him sadness," and this was no doubt true of his treatment of Lacan in Anti-Oedipus. ${ }^{26}$ In return, Lacan once said of a book critical of his work, "I have never been so well read-with so much love," and one can almost imagine him making the same remark of Anti-Oedipus. ${ }^{27}$ Perhaps one day, someone with the competence and patience will provide us with a more complete reading of the way in which Deleuze took up and developed Lacan's thought - and perhaps the way in which Lacan took up and develops Deleuze's insights in his later work. Žižek, unfortunately, is not that person. Organs without Bodies: Deleuze and Consequences is a fascinating romp through the Žižekian universe, full of penetrating insights and illuminating jokes, but as a reading of Deleuze it adds little to our understanding. The best place we have to go, still, for a Lacanian appreciation of Deleuze is not Žižek, but rather . . Lacan himself.

Purdue University

\section{Notes}

1. Gilles Deleuze, Masochism: Coldness and Cruelty, trans. Jean McNeil (New York: Zone Books, 1989).

2. Gilles Deleuze and Félix Guattari, Anti-Oedipus: Capitalism and Schizophrenia, trans. Robert Hurley, Mark Seem, and Helen R. Lane (1972; Minneapolis: University of Minnesota Press, 1983).

3. "Le 'Je me souviens' de Gilles Deleuze" (interview by Didier Eribon) in Le Nouvel Observateur 1619 (16-22 November 1995), 50-51.

4. Gilles Deleuze, Foucault, trans. Sean Hand (Minneapolis: University of Minnesota Press, 1886), 42. Deleuze was speaking of Virilio's relation to Foucault.

5. See Alain Badiou, Deleuze: The Clamor of Being, trans. Louise Burchill (Minneapolis: University of Minnesota Press, 2000), 3-4.

6. Gilles Deleuze, Logic of Sense, trans. Mark Lester and Charles Stivale; ed. Constantin V. Boundas (New York: Columbia University Press, 1988), 124. See also p. 96: "How 
are we to reconcile these two contradictory aspects [of sense]? On one hand, we have impassibility in relation to states of affairs and neutrality in relation to propositions; on the other hand, we have the power of genesis in relation to propositions and in relation to states of affairs themselves."

7. Gilles Deleuze "Control and Becoming," interview with Antonio Negri, in Negotiations, 1972-1990, trans. Martin Joughin (New York: Columbia University Press, 1995), 170. Elie Sambar was the editor of the Revue des études palestiniennes.

8. Gilles Deleuze, Desert Islands and Other Texts, 1953-1974, ed. David Lapoujade, trans. Michael Taormina (New York: Semiotext(e), 2004), 261, in the discussion following "Nomad Thought."

9. Deleuze, "On Philosophy," in Negotiations, 144.

10. Gilles Deleuze and Claire Parnet, Dialogues, trans. Hugh Tomlinson and Barbara Habberjam (New York: Columbia University Press, 1987), 81.

11. Deleuze, "Capitalism and Schizophrenia," in Desert Islands, 234.

12. Eugene Holland's Deleuze and Guattari's Anti-Oedipus: Introduction to Schizoanalysis (New York: Routledge, 1999) is an excellent analysis of Anti-Oedipus, though it treats Deleuze's links with Lacan only in passing (see, e.g., 89-91).

13. Gilles Deleuze and Félix Guattari, What Is Philosophy? trans. Hugh Tomlinson and Graham Burchell (New York: Columbia University Press, 1991), 47.

14. Ibid.

15. Immanuel Kant, Critique of Judgment, trans. James Creed Meredith (Oxford: Oxford University Press, 1952), Introduction, 3, footnote 1, 16.

16. Jacques Lacan, "Kant avec Sade, in Écrits (Paris: Seuil, 1966), 765-90. For Deleuze's use of Lacan's reading of Sade, see his "Humor, Irony, and the Law," in Masochism, 81-90.

17. Deleuze and Guattari, Anti-Oedipus, 26-27. At one point, Deleuze and Guattari describe the project of Anti-Oedipus in explicitly Kantian terms: "In what he termed the critical revolution, Kant intended to discover criteria immanent to understanding so as to distinguish the legitimate and the illegitimate uses of the syntheses of consciousness. In the name of transcendental philosophy (immanence of criteria), he therefore denounced the transcendent use of the syntheses such as appeared in metaphysics. In a like fashion, we are compelled to say that psychoanalysis has its metaphysics - its name is Oedipus. And that a revolution — this time materialist—can proceed only by way of a critique of Oedipus, by denouncing the illegitimate use of the syntheses of the unconscious as found in Oedipal psychoanalysis, so as to rediscover a transcendental unconscious defined by the immanence of its criteria, and a corresponding practice that we shall call schizoanalysis" (75).

18. Deleuze, "The Method of Dramatization," in Desert Islands, 115.

19. See Gilles Deleuze, "Louis Wolfson; or, The Procedure," in Essays Critical and Clinical, trans. Daniel W. Smith and Michael A. Greco (Minneapolis: University of Minnesota Press, 1997), 7-22. See also Anti-Oedipus, 310: "Elisabeth Roudinesco has clearly seen that, in Lacan, the hypothesis of an unconscious-as-language does not closet the unconscious in a linguistic structure, but leads linguistics to the point of its autocritique, by showing how the structural organization of signifiers still depends on a despotic Great Signifier acting as an archaism." 
20. In Logic of Sense, the distinction between surface and depth is paralleled in the difference between Lewis Carroll (surface) and Antonin Artaud (depth), but Deleuze's preference for Artaud and the dimension of depth (rather than surface) is already evident: "We would not give a page of Artaud for all of Carroll. Artaud is alone in having been an absolute depth in literature, and in having discovered a vital body and the prodigious language of this body" (93).

21. Judith Butler, for instance, characterizes Deleuze and Guattari's conception of desire as "an originary unrepressed libidinal diversity subject to the prohibitive laws of culture," an ahistorical or "pre-cultural ideal" à la Rousseau or Montesquieu, a "natural eros which has subsequently been denied by a restrictive culture," arguing that Deleuze and Guattari promise "a liberation of that more original, bounteous desire." See Judith Butler, Subjects of Desire (New York: Columbia University Press, 1999), 214-15, 206. Žižek, happily, does not fall into this trap.

22. See Gilles Deleuze, "Desire and Pleasure," in Foucault and His Interlocutors, ed. Arnold I. Davidson (Chicago: University of Chicago Press, 1997), 185-86, and Gilles Deleuze and Félix Guattari, A Thousand Plateaus, trans. Brian Massumi (Minneapolis: University of Minnesota Press, 1981), 215.

23. See Deleuze, "Desire and Pleasure," 186.

24. See Deleuze, seminar of 21 December 1971. Transcripts of many of Deleuze seminars are available online at www.webdeleuze.com, thanks to the efforts of Richard Pinhas.

25. Deleuze, "On Anti-Oedipus," in Negotiations, 13-14, translation modified; italics added.

26. Deleuze and Parnet, Dialogues, 119.

27. Jacques Lacan, On Feminine Sexuality, the Limits of Love and Knowledge: The Seminar of Jacques Lacan, Book 20, Encore, ed. Jacques-Alain Miller, trans. Bruce Fink (New York: Norton, 1999), 62. I would like to thank Emily Zakin for this reference. Lacan was speaking of Jean-Luc Nancy and Philippe Lacoue-Labarthe, The Title of the Letter: A Reading of Lacan [1973], trans. François Raffoul and David Pettigrew (Albany: SUNY Press, 1992). 


\section{טE,

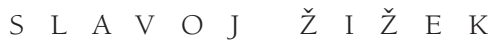 \\ Notes on a Debate "From Within the People"}

My FIRST SURPRISE IN reading Daniel W. Smith's critique of my Deleuze book is his insistence on how I use Deleuze only in order to "Lacanize" him, not being attentive to Deleuze's precise line of argumentation . . . look who's talking! Is, of all philosophers, Deleuze not the one known for his ruthlessly appropriative reading of other philosophers, for using them as vehicles to articulate his line of thought! Linked to this is my second surprise: after outlining his basic point about Lacan and Deleuze (how Deleuze was effectively much closer to Lacan than it may appear, how Anti-Oedipus aims at saving Lacan from Lacanians, etc.), one would expect Smith to confront (critically reject or whatever) my specific reading of Deleuze: the central thesis on two heterogeneous currents in his thought (becoming as the impassive sterility of the event versus becoming as the generative process), the insistence on Deleuze's disavowed proximity not only to Lacan but also to Hegel, and so forth. What we get instead of this is the expanded version of the standard "Deleuzian" party line on Lacan: it is already Lacan who, especially in his late writings, breaks out of the Oedipal constraints, searching for a more direct approach to the texture of the Real; in their Anti-Oedipus, Deleuze and Guattari merely want to go further (to the end) in this direction. All the principal concepts of Anti-Oedipus, from "body without organs" to flux of desire, are different names for the pre-Oedipal libidinal dynamics of the Real, for a multitude not yet totalized into a One through the Oedipal prohibition.

My reply to this line of thought is that it misses the point of the Lacanian Real: the Real, for Lacan, is in itself thwarted, the name for the gap of a radical "negativity," it stands for a paradoxical (non)entity that has no ontological consistency in itself, but can only be discerned retroactively, from its effects, as their absent Cause. For this reason, for Lacan, to "go to the end" and approach "the Real in itself" is precisely what one should not do. Nowhere is this difference more palpable than in the different ways Lacan and Deleuze deal with the relationship between neurosis (hysteria) and perversion. Deleuze and Guattari ultimately 
condone the standard "libertarian" approach: neurosis (as exemplified by the feminine hysteria) is a compromise formation, a half-protest against the oppressive Law that simultaneously remains attached to it, while a perverse subject "goes to the end," directly enacting what the neurotic subject is only able to fantasize about. Lacan, however, restores hysteria to its Freudian place of honor, agreeing with Freud that a perversion, far from directly displaying the unconscious, blocks the access to it most thoroughly-nowhere is the unconscious more occluded than in perversion.

In other words, my thesis is that in Anti-Oedipus Deleuze/Guattari do to Lacan what Carl Gustav Jung did to Freud. Remember that for Jung also, the Freudian unconscious was not yet the deeper "real" unconscious, the impersonal domain of collective archetypes; it remained caught in the superficial social and familial web. No wonder, then, that an admiration of Jung is Deleuze's corpse in the closet: the fact that Deleuze borrowed a key term (rhizome) from Jung is not a mere insignificant accident_rather, it points toward a deeper link. ${ }^{1}$ In his early text on Sacher-Masoch (1961), Deleuze extensively relies on Jung in his critique of Freud. ${ }^{2}$ His reproach to Freud concerns three clearly interconnected features. First, because of his focus on the figure of the father, Freud neglects the key role of the woman (Mother) in masochism: the masochist contract is a contract with the all-devouring Mother; as such, masochism stages a "regression" toward the earlier period of (individual and collective) history in which women played a crucial role in society-Sacher-Masoch cannot be properly understood without Bachofen. Second, the Freudian unconscious remains the "superficial" hysterical unconscious, the unconscious of an individual caught in the Oedipal struggle with the paternal authority; Freud ignores the deeper collective (preindividual) strata of the "maternal" unconscious-that is, he does not "enter into the profound dimensions where the image of the Mother reigns in its own terms." Third, Freud denies the symbolic autonomy to the unconscious, reducing it to a shadow theater reflecting what goes on in nonsymbolic reality, either in real social life or in the biological real of the instincts. In contrast to Freud, Jung was much more sensitive to all of these three features: he was aware of the key fundamental role of the maternal principle later repressed by the paternal one; he clearly identified the need to penetrate beneath the "superficial" hysterical-individual-Oedipal unconscious to the collective pre-Oedipal one; and he elaborated the autonomous universe of primordial symbols ("imagoes"), which are not to be interpreted as pointing toward another reality, but are themselves the unsurpassable horizon of meaning: "It was not left to/Freud/to grasp the role of original Images. / . . . The irreducible datum of the unconscious is the symbol itself, and not an ultimate symbolized." This crucial difference between Freud and Jung determines the radically different approach to therapeutic practice: for Freud, the goal of analysis is the interpretation of the neurotic symptom; its meaning is thereby 
consciously appropriated by the subject, and the symptom dissolves. Jung, on the contrary, accomplishes the key step from psycho-analysis to psycho-synthesis: his goal is not just to analyze the symptoms, but to enable the subject to accept as part of his personality the repressed content of the primordial Images (say, to accept that the pre-Oedipal maternal dimension is no less part of his personality than the dominant paternal one). The patients are "to be reconciled with themselves, that is, to reintegrate in their personality those very parts which they neglected to develop, and which are as if alienated in Images, where they lead a dangerously autonomous life."

There is thus a direct lineage from Jung to Anti-Oedipus: the idea that beneath the "superficial" Freudian unconscious in alliance with consciousness there is the "true" impersonal unconscious that explodes the Oedipal triangle has Jungian origins written all over it. In this way, of course, the whole point of Freud's discovery of the unconscious is missed: it is not a simple "decenterment" toward a more "fundamental" unconscious as the true center of human personality, but, on the contrary, the total desubstantialization of the unconscious-Freud's whole point is to separate his unconscious from the impersonal "primitive" unconscious of Lebensphilosophie. This reference to Jung also prevents Deleuze from fully deploying and properly understanding the consequences of his own elaboration of the notion of the "masochist contract," that is, of the way this contract (with the woman to whom the masochist cedes authority) undermines the paternal authority:

the application of the paternal law is delivered back into the hands of the Woman or the Mother. The masochist holds out for something specific in this transference: that the pleasure that the law forbids be given to him precisely through the means of the law. For the pleasure that the paternal law forbids, he will taste through the law, as soon as the law in all its severity is applied to him by the woman.... his extreme submission signifies that he is offering up the father and the paternal law to derision. ... The same law which forbids me from realizing a desire on pain of the consequent punishment is now the law which puts the punishment first and orders me accordingly to satisfy the desire: here we have a properly masochistic form of humour.

What Deleuze does not fully take into account is the strictly limited nature of the masochist "regression": far from simply "regressing" from the paternal to the maternal level, the masochist, while remaining within the domain of the paternal (contract), reintroduces the Woman as the partner in the contract—not in order to fully enjoy the Woman, but in order to mockingly undermine the paternal authority. The masochist thus stages an uncanny short-circuit, a monstrous travesty of the Law: in her very elevation to the undisputed Master, whose every whim 
the masochist is obliged to obey, the Woman is turned into a puppet effectively controlled by her slave, who controls the game, writing its rules-the explicit asymmetry of the masochist contract (at the level of enunciated: man's subordination to woman) relies on then opposite asymmetry at the level of the position of enunciation. The humor of masochism is therefore not directed only at the figure of the father; it relies on the ridiculous (and, simultaneously, monstrous) incompatibility or discord between the symbolic place of symbolic power and the element who occupies it. Is therefore masochism, the masochist contract, not the ultimate proof of the fact that "Woman is one of the Names-of-theFather"? To put it in Lacan's terms, the wager (and the deception) of the masochist is that the Woman exists. Deleuze's "the Woman or the Mother" is here indicative; for Lacan, the Woman ( La Femme) only exists qua Mother (quod matrem) - where, then, is there a place for a woman who is not Mother, for the void of feminine subjectivity proper? It is significant that Deleuze does not mention here the notion of superego-in contrast to the symbolic Law, superego is precisely the law (commandment), which is not prohibitive, which is not yet disjunct from enjoyment.

If I pass in silence over Kaufman's review of Badiou's and my Deleuze books, it is simply because I basically agree with her (inclusive of her critical call for more betrayal of Deleuze). So let me just conclude with a brief remark on how I see the difference between Heidegger, Deleuze, and Badiou with regard to the Event.

The shift from substantial Reality to (different forms of) Event is one of the defining features of modern sciences: quantum physics posits as the ultimate reality not some primordial elements, but, rather, some kind of string "vibrations," entities that can only be described as desubstantialized processes; cognitivism and system theory focus on the mystery of "emerging properties," which also designate purely processual self-organizations, and so forth. No wonder, then, that the three crucial contemporary philosophers-Heidegger, Deleuze, Badiou-deploy three thoughts of the Event: in Heidegger, it is the Event as the epochal disclosure of a configuration of Being; in Deleuze, it is the Event as the desubstantialized pure becoming of Sense; in Badiou, it is the Event the reference to which grounds a Truth-process. For all three of them, Event is irreducible to the order of Being (in the sense of positive reality), to the set of its material (pre)conditions. For Heidegger, Event is the ultimate horizon of thought, and it is meaningless to try to think "behind" it and to render thematic the process that generated it-such an attempt equals an ontic account of the ontological horizon. For Deleuze, one cannot reduce the emergence of a new artistic form (film noir, Italian neo-realism, etc.) to its historical circumstances, or account for it in these terms. For Badiou, a Truth-Event is totally heterogeneous with regard to the order of Being (positive reality). Although, in all three cases, Event stands for historicity proper (the explosion of the New) versus historicism, differences 
between the three philosophers are crucial, of course. For Heidegger, Event has nothing to do with ontic processes; it designates the "event" of a new epochal disclosure of Being, the emergence of a new "world" (as the horizon of meaning within which all entities appear). Deleuze is a vitalist, insisting on the absolute immanence of the Event to the order of Being, conceiving Event as the One-All of the proliferating differences of Life. Badiou, on the contrary, asserts the radical "dualism" between Event and the order of Being.

However, what unites them above this difference is that both perform the same paradoxical philosophical gesture of defending, as materialists, the autonomy of the "immaterial" order of the Event. As a materialist, and in order to be thoroughly materialist, Badiou focuses on the idealist topos par excellence: How can a human animal forsake its animality and put its life in the service of a transcendent Truth? How can the "transubstantiation" from the pleasure-oriented life of an individual to the life of a subject dedicated to a Cause occur? In other words, how is a free act possible? How can one break (out of) the network of the causal connections of positive reality and conceive of an act that begins by and in itself? In short, Badiou repeats within the materialist frame the elementary gesture of idealist anti-reductionism: human Reason cannot be reduced to the result of evolutionary adaptation; art is not just a heightened procedure of providing sensual pleasures, but a medium of Truth; and so on. Additionally, against the false appearance that this gesture is also aimed at psychoanalysis (is not the point of the notion of "sublimation" that the allegedly "higher" human activities are just a roundabout "sublimated" way to realize a "lower" goal?), therein resides already the significant achievement of psychoanalysis: its claim is that sexuality itself, sexual drives pertaining to the human animal, cannot be accounted for in evolutionary terms. ${ }^{3}$ This makes clear the true stakes of Badiou's gesture: in order for materialism to truly win over idealism, it is not enough to succeed in the "reductionist" approach and demonstrate how mind, consciousness, and so forth can nonetheless somehow be accounted for within the evolutionary-positivist frame of materialism. On the contrary, the materialist claim should be much stronger: it is only materialism that can accurately explain the very phenomena of mind, consciousness, and so forth; and, conversely, it is idealism that is "vulgar," that always already "reifies" these phenomena.

From my youth I recall the old Maoist distinction between the contradictions within the people to be resolved through democratic debate, and the contradictions between the people and the enemies of the people to be resolved through merciless struggle-my final claim is simply that the differences between Deleuze, Lacan, and Badiou are of the first type, the differences "within the people"- a debate is possible here. 


\section{Notes}

1. "Life has always seemed to me like a plant that lives on its rhizome. Its true life is invisible, hidden in the rhizome. . . What we see is the blossom, which passes. The rhizome remains." C. G. Jung, Memoirs, Dreams, Reflections (New York: Vintage Books, 1965), 4.

2. See Gilles Deleuze, "From Sacher-Masoch to Masochism," originally published as "De Sacher-Masoch au Masochisme" in Arguments, no. 21 (1961); translation by Christian Kerslake to appear in Angelaki.

3. This is how one should locate the shift from the biological instinct to drive: instinct is just part of the physics of animal life, while drive (death drive) introduces a metaphysical dimension. In Marx we find the homologous implicit distinction between working class and proletariat: "working class" is the empirical social category, accessible to sociological knowledge, while "proletariat" is the subject-agent of revolutionary Truth. Along the same lines, Lacan claims that drive is an ethical category. 